\title{
The development of mathematics teacher professional competencies through social media
}

\author{
Al Jupri *, Rini Marwati, Ririn Sispiyati, Rizky Rosjanuardi \\ Department of Mathematics Education, Universitas Pendidikan Indonesia, West Java, Indonesia \\ *Correspondence: aljupri@upi.edu \\ (c) The Author(s) 2022
}

\begin{abstract}
One of the competencies for mathematics teachers that needs to be developed continuously is professional competence. However, even if efforts for developing teachers' competencies have been made formally by the government, it seems still lacking. This study, therefore, aims to develop mathematics teacher professional competencies through an informal development model using social media. This research used a qualitative method, a case study design, involving 19 mathematics teachers from various regions in Indonesia in the informal development process in the range of 2019-2021. The informal approach was carried out using question-and-answer techniques and guided discussions on mathematical problems. From the teacher development processes, 30 mathematics problems and their solutions were collected. As an illustration of this development process, this article presents five problems and their solutions, including solutions for two mathematics problems on conceptual understanding and three mathematics problems on problem-solving. We conclude that this informal approach is fruitful in helping mathematics teachers solve mathematics problems. This study implies that the teacher development process carried out in this study can be used as a model for informal teacher development by other higher education academics in their respective places.
\end{abstract}

Keywords: conceptual understanding; informal teacher development model; problem solving in mathematics; professional development of mathematics teachers

Received: 19 December 2021 | Revised: 21 December 2021

Accepted: 2 January 2022 | Published: 6 January 2022 


\section{Introduction}

According to Law Number 14 of 2005 concerning Teachers and Lecturers, four competencies need to be possessed by a teacher in Indonesia, namely professional competencies, pedagogic competencies, personality competencies, and social competencies (Presiden Republik Indonesia, 2005). These competencies refer respectively to the mastery of the subject matter for the field of study; mastery of theory and skills in implementing and evaluating teaching and learning processes; possession of a personality that is steady, stable, wise, authoritative, exemplary, and having a noble character; and the ability to communicate effectively with students, education staff, parents or guardians of students, and the local communities (Anggranei, 2020; Firman, 2007). Again, according to the Law on Teachers and Lecturers (Presiden Republik Indonesia, 2005), teachers, including mathematics teachers, have the right to obtain training and professional teacher development according to their respective study fields. Particularly in mathematics education, mathematics teachers have the right to obtain training and professional development in the field of mathematics and of corresponding teaching and learning skills.

Through education and training institutions at either national or regional levels, the Indonesian government has been and continues to provide teacher development to teachers (Mustofa, 2007; Rerendo et al., 2021; Suwartini, 2017), including to mathematics teachers. However, considering many teachers' populations in Indonesia, the teacher development efforts are often deemed inadequate. The lack of teacher development efforts has been helped more or less in the form of teacher training, and teacher development by practitioners, private educational institutions, non-profit educational institutions, research projects, and service to non-profit organizations, as well as by community service activities carried out by higher education institutions (Apud, 2020; Jupri \& Rosjanuardi, 2020). For example, through lesson study activities fostered by university lecturers, science and mathematics teachers in Jawa Barat (West Java) obtained a teacher development program for improving pedagogic and professional competencies (Hendayana, 2007; Rohayati, 2008).

Even if the teacher development through lesson study is considered very good, the processes and activities of the development are limited in the scope of formal settings (Firman, 2007; Prihantoro, 2011). Based on the facts, experiences, and observations, when teachers encounter problems regarding professional competencies that require conceptual understanding or problem-solving immediately, formal teacher development is felt to be lacking. Conceptual understanding, particularly in mathematics, includes not procedural understanding but also relational understanding that relates to various mathematical concepts (Jupri et al., 2021; Skemp, 1976). Meanwhile, problem-solving, which needs higher-order thinking skills, requires teachers to think critically, creatively, and non-routinely (Jupri et al., 2020; Koichu \& Leron, 2015; Polya, 1973; Posamentier \& Stepelman, 1990; Samo, 2017). Therefore, the formal teacher development needs to be completed, for instance, by using the informal teacher development approach (Bissessar, 2014; Patahuddin \& Logan, 2019).

Informal teacher development can be carried out, for example, through direct discussion and question-and-answer techniques between teachers and university lecturers through various communication media, including social media, such as Facebook, Instagram, 
and WhatsApp (Bissessar, 2014; Patahuddin \& Logan, 2019). In this article, we present the results of our study aimed at developing mathematics teacher professional competencies through an informal approach with the help of social media as a tool of communication and interactions. The teacher development process is carried out continuously, which is not restricted by space and time as well as by formal working hours. This type of teacher development can be seen as an academic contribution to the mathematics teacher community who need assistance in solving mathematical problems encountered in their daily teaching and learning processes.

\section{Methods}

This study used a qualitative method, a case study design, with the following process. Research activities to develop the professional competence of mathematics teachers were carried out informally through discussions and question-and-answer techniques via social media in the range of 2019-2021. Social media, used for communication and interactions between mathematics teachers and the research team as university lecturers, include Facebook, Instagram (via the features of Message and Comments), and WhatsApp (via the features of Chats and Video Call).

Mathematics teachers participated in this study include teachers who have ever participated in training or teacher development activities instructed by the research team, teachers who have been instructed by the research team or individuals among the research team, old friends of the research team members who have become teachers, and former mathematics education students of the research team members who are now on duty as mathematics teachers. During the range of 2019 to 2021, 19 teachers informally asked for help from the research team to solve mathematics problems they faced in their respective schools. These teachers work at the elementary school (five teachers, two males, and three females), junior high school (eight teachers, five males, and three females), and senior high school or equivalent levels (six teachers, four males, and two females). The teachers come from various regions in Indonesia, including Aceh, South Sumatra, Banten, West Java, Jakarta, Central Java, West Kalimantan, South Sulawesi, and East Nusa Tenggara. The mathematics problems that are asked and discussed can be classified into types of conceptual understanding and problem-solving problems. Figure 1 shows some screenshots of the problems asked by one of the teachers through the Message feature on Facebook. Through this feature, responses to the teacher problems are given by writing down solutions on papers, then taking pictures and uploading them as replies to the proposed problems (see Figure 1). Figure 2 presents an example of mathematics problems that are posed through the Chats feature on WhatsApp along with its response. 


5/1/20, 9:23 PM
SImat mlam bapa,,
maaf mngganggu,,mau
tanya ne bapa,, ada
soal jajar
genjang, diketahui
panjang sisinya,, trus di
tanya Luasnya tanpa
diketahui tinggi jajar
genjangnya...
Gmna mnylesaikannya
pa???
Mkash
Ini soalnya pa

Translation: Good evening sir. Apologize for bothering you. I have a problem: It is known that a parallelogram with the length of its sides are known. What is the area of the parallelogram if the altitude is not known? How do we solve this problem, sir? Thank you.

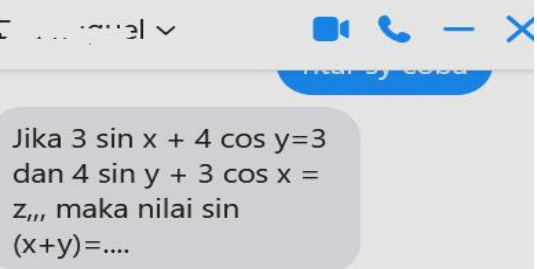

$(x+y)=\ldots$

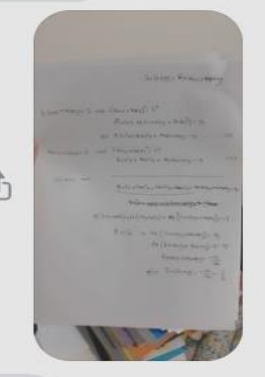

Mkasih bnyak bpa...

Translation: If $3 \sin x+4 \cos y=3$ and $4 \sin y+3 \cos x=\mathrm{z}$, then the value of $\sin (x+y)=\ldots$

Thank you sir.

Figure 1. An example of proposed problems via Facebook and its response

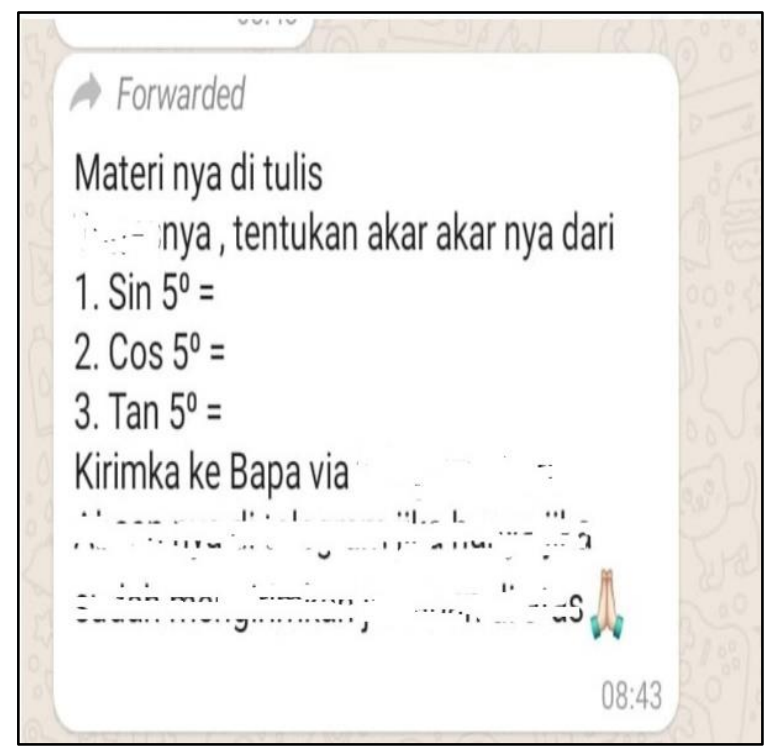

Translation: The material should be written. Find the roots for $1 . \operatorname{Sin} 5^{\circ}=. .2 . \operatorname{Cos} 5^{\circ}=\ldots 3$. Tan $5^{\circ}=\ldots$. Please send to me.

Figure 2. An example of proposed problems via WhatsApp and its response

When there is a problem posed by the teacher personally to one of the research teams, and if it can be answered immediately, then it will be answered personally to the teacher directly. If it cannot be answered immediately, it will be discussed first, and then the answer will be sent.

From many interactions with the mathematics teachers, 30 mathematics problems were collected: Eight mathematics problems came from elementary school teachers, 12 problems 
from junior high school mathematics teachers, and ten problems from senior high school mathematics teachers. Most of the problems and responses are still neatly recorded on Facebook, Instagram, and WhatsApp social media. However, some of the problems proposed via WhatsApp were lost because they were accidentally deleted. Next, the data regarding the collection of problems, solutions, and the process of developing professional competence in mathematics were analyzed based on conceptual understanding and a problemsolving framework. The results of the analysis then are presented in this article.

\section{Results}

The main results of the informal professional competence development of mathematics teachers that have been carried out are in the form of a collection of problems grouped by education level and based on the type of mathematics problems. The collection of the problems based on the level of education is then given notes and comments accompanied by examples of descriptions of the solutions to the collected problems.

\section{Collection of mathematics problems and examples of responses for elementary school teachers}

Table 1 presents a collection of mathematics problems from elementary school teachers. The editorial texts for the problems have been adjusted so that readers can understand them in general. In addition, the collection of problems is classified into two types of problems: conceptual understanding and problem-solving types. As presented in Table 1, five problems are classified into the conceptual understanding type, and three problems are classified into problem-solving types.

Table 1. Collection of mathematics problems from elementary school teachers

\begin{tabular}{|c|c|}
\hline $\begin{array}{c}\text { Type of } \\
\text { Problems }\end{array}$ & Mathematics Problems \\
\hline $\begin{array}{c}\text { Conceptual } \\
\text { Understanding }\end{array}$ & $\begin{array}{l}\text { (1)What are the differences between } 3 \times 4 \text { and } 4 \times 3 \text { ? } \\
\text { (2)Why is in the division of two fractions the procedure the same as } \\
\text { multiplying the first fraction with the multiplicative inverse of the } \\
\text { second fraction? } \\
\text { (3)Why is a positive number multiplied by a negative number the result is } \\
\text { a negative number, a negative number is multiplied by a negative } \\
\text { number the result is a positive number? } \\
\text { (4)Where did the procedure for dividing two (positive) integers come } \\
\text { from? Why is the procedure like that? } \\
\text { (5)Is it always } 10-1=9 \text { ? Why are there religious leader say } 10-1=19 \text { ? } \\
\text { (6) Two workers paint the walls of a house. If the work is done alone by } \\
\text { Mr. Bondan, it will take } 8 \text { hours. Meanwhile, if Mr. Cepi did it himself, } \\
\text { it would take } 6 \text { hours. How long will it take for this work to be } \\
\text { completed if it is done together by Mr. Bondan and Mr. Cepi? } \\
\text { (7)Every three hours from } 03: 00 \text { to } 12: 00 \text { AM the air temperature rises by } \\
\text { two degrees Celsius. If the air temperature at } 05: 00 \text { AM is }-2 \text { degrees } \\
\text { Celsius, then what is the air temperature at } 11: 00 \text { AM? }\end{array}$ \\
\hline
\end{tabular}




\begin{tabular}{|c|c|}
\hline $\begin{array}{c}\text { Type of } \\
\text { Problems }\end{array}$ & Mathematics Problems \\
\hline $\begin{array}{l}\text { Problem } \\
\text { Solving }\end{array}$ & $\begin{array}{l}\text { (8) Three friends entered an inn. The officer said, the price for renting a } \\
\text { room for three is Rp300,000. Each collects Rp100,000 to pay for it. } \\
\text { After the three people went to the room, the officer realized that the } \\
\text { room rental price should only be Rp250,000. Then the officer handed } \\
\text { over Rp50,000 to the three people. Because the Rp50,000 was in the } \\
\text { Rp10,000 denomination, the officer only handed over Rp30,000 to the } \\
\text { three people, while the Rp20,000 was kept for him. The Rp30,000 } \\
\text { money was divided among the three people, Rp10,000 each. So, if it is } \\
\text { calculated, each person only pays Rp90,000. So, the three of them } \\
\text { actually pay } 3 \text { x Rp } 90,000=\mathrm{Rp} 270,000 \text {. When added to the Rp20,000 } \\
\text { bill that the officer holds, the total is Rp290,000. So where is the other } \\
\text { Rp10,000? }\end{array}$ \\
\hline
\end{tabular}

As illustrations below, we present two examples of responses to the proposed problems from elementary school teachers. Example 1 presents a problem that requires conceptual understanding in mathematics and its solution. The solution starts from a concrete example, and next, it is mentioned that the concrete example can be generalized into general cases. When discussing this problem, the elementary teacher needed more explanation, not only using textual explanation via Chat feature but also using a Video Call feature via WhatsApp. The solution below is the summary of the discussion we had carried out.

Example 1. Why is in the division of two fractions the procedure the same as multiplying the first fraction with the multiplicative inverse of the second fraction?

[Problem 2 from Table 1.]

\section{Solution.}

Let us consider a division of $3 / 2$ divided by 1/4. The process of this division can be presented as follows:

$$
\frac{3}{2} \div \frac{1}{4}=\frac{\frac{3}{2}}{\frac{1}{4}}=\frac{\frac{3}{2} \times 4}{\frac{1}{4} \times 4}=\frac{\frac{3}{2} \times 4}{1}=\frac{3}{2} \times 4=\frac{3}{2} \times \frac{4}{1}=\frac{12}{2}=6
$$

From the example above, it can be seen that in order that the fraction $\frac{\frac{3}{2}}{\frac{1}{4}}$ has denominator 1, then 1/4 must be multiplied by 4. To make the fraction has the same value as the initial fraction, then the numerator (namely 3/2) must be multiplied also by 4. As a consequence, the division process is carried as the above process. In general, this procedure can be used for general cases for division of two fractions, a/b is divided by $c / d$.

Example 2 presents a problem that requires problem solving ability and its response. The problem presented in Example 2 is a type of problem solving problem because the standard procedure for solving it cannot be found immediately. Problems like this often appear in mathematics competitions. In addition, as shown in the description of the solution, the solution involves variables that are part of the algebra topic.

Example 2. Two workers paint the walls of a house. If the work is done alone by Mr. Bondan, it will take 8 hours. Meanwhile, if Mr. Cepi did it himself, it would 
take 6 hours. How long will it take for this work to be completed if it is done together by Mr. Bondan and Mr. Cepi? [Problem 6 from Table 1.]

\section{Solution.}

In 1 hour Mr. Bondan can finish $\frac{1}{8}$ of the total work. In 1 hour Mr. Cepi can finish $\frac{1}{6}$ of the total work. Let that both workers together can finish in m hours. This means that in 1 hour they together can finish $\frac{1}{m}$ of the total work. From this description, therefore, the work done together can be written as $\frac{1}{8}+\frac{1}{6}=\frac{1}{m}$. We need to find $m$, which can be determined as follows:

$$
\begin{aligned}
& \frac{1}{8}+\frac{1}{6}=\frac{1}{m} . \\
& \frac{1}{m}=\frac{3+4}{24}=\frac{7}{24} . \\
& m=\frac{24}{7}=3 \frac{3}{7} .
\end{aligned}
$$

So, Mr. Bondan and Mr. Cepi can finish the work together in $3 \frac{3}{7}$ hours.

The above two solutions, as responses to the teachers' problems, in practice are carried out in an informal and relaxed situation. In this way, the teachers do not feel reluctant to ask questions or to discuss if there are things that are not clear. As the case of Example 1, often when the responses are not understood yet, the teachers try to keep asking questions not only by Chats but also by Video Call features, so that clarifications and explanations are given again until they can be understood properly.

\section{Collection of mathematics problems and examples of responses for junior high school teachers}

Table 2 presents a collection of mathematics problems proposed by junior high school mathematics teachers. As in Table 1, the editorial texts in Table 2 have been improved to make them easier to understand. The collected mathematics problems are classified into conceptual understanding and problem-solving types of problems. Some of the problems of problemsolving types are relatively popular, originating from mathematics competitions. In addition, there are also open-ended problems whose solutions and solution strategies are open. We have 12 problems in total from the data collection: Four problems are conceptual understanding type,

\begin{tabular}{|c|c|}
\hline $\begin{array}{c}\text { Type of } \\
\text { Problems }\end{array}$ & Mathematics Problems \\
\hline $\begin{array}{l}\text { Conceptual } \\
\text { Understanding }\end{array}$ & $\begin{array}{l}\text { (1) Is } 0 \text { a multiple of } 2 \text { ? Is } 0 \text { also a multiple of } 3 \text { ? Why? } \\
\text { (2) What are the differences between variables, constants, and coefficients? } \\
\text { (3) Why are } 40 \% \text { and } 20 \% \text { discounts on an item not the same as } 60 \% \\
\text { discount? } \\
\text { (4) How to factorize the quadratic form } a x^{2}+b x+c \text { ? Explain why is the } \\
\text { procedure of the factorization correct? }\end{array}$ \\
\hline & $\begin{array}{l}\text { (5) On a trip that covers a certain distance, if car A is moving at an average } \\
\text { speed of } 50 \mathrm{~km} / \text { hour, then the car will be two hours late in reaching its }\end{array}$ \\
\hline
\end{tabular}
and eight problems are problem-solving types.

Table 2. Collection of mathematics problems from Junior High School Teachers 


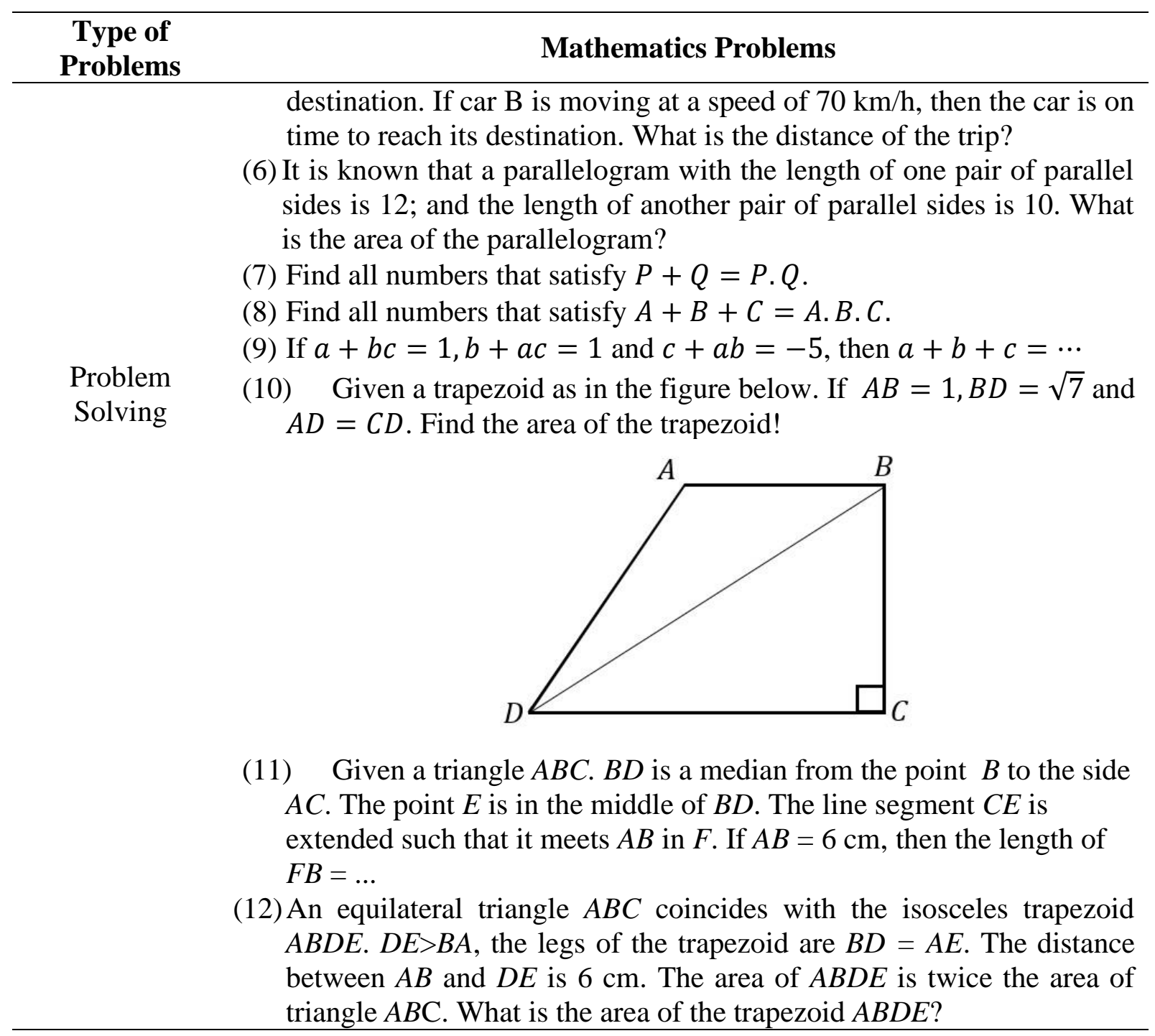

In the following, we present two examples of solutions as responses to the problems proposed by junior high school mathematics teachers. Example 3 presents solution to the problem that is classified into the conceptual understanding type of problem. The main topic of the problem in this example is the topic of social arithmetic, particularly for the concept of percentage. It can be seen in the description of the solution, the problem is easier to understand when taking simple concrete examples. After that, the algebraic generalization process can be carried out.

Example 3. Why are $40 \%$ and $20 \%$ discounts on an item not the same as $60 \%$ discount? [Problem 3 from Table 2.]

\section{Solution.}

Let us take an example of a price of an item Rp100,000. When this price gets the discount $40 \%(40 \% \times 100,000=40,000)$, then the price that should be paid is Rp60,000. Next, the price Rp60,000 gets a discount of $20 \%(20 \% \times 60,000$ $=12,000$ ). Therefore, the final price of the item that should be paid is Rp60,000 $R p 12,000=R p 48,000$.

Meanwhile, if the price of the item is Rp100,000 and it gets discount of 60\% $60 \%$ $\mathrm{x} 100,000=60,000)$, then the price that should be paid is Rp100,000-Rp60,000= Rp40,000. 
Using similar procedure as the above process, we can assume the price of an item as $X$, and so on until we know the difference between the impact of the $40 \%$ plus $20 \%$ discount and the $60 \%$ discount directly.

Example 4 below presents the solution to Problem 8 in Table 2. This problem is a type of problem-solving problem because the standard procedure for solving it is not yet known. It appears that the problem in Example 4, apart from being a type of problem-solving, can also be said to be an open-ended problem, with a variety of correct answers and a wide range of possible solution strategies. The existence of these open-ended problems is seen as being able to develop aspects of creative thinking, either in terms of flexibility, fluency, or originality (Kwon et al., 2006).

Example 4. Find all numbers that satisfy $A+B+C=A$. B. C. [Problem 8 from Table 2.]

Solution.

Let $A, B$, and $C$ be any real numbers, respectively. By trial and error, for example, if we choose $A=0$, then we will get $B+C=0$ or $B=-C$. By choosing any number for $B$ or $C$, we will get an infinite number of solutions to the equation. For example, if $B=7$ is selected, then $C=-7$. So the solution to the equation is $A=0, B=7, C$ $=-7$.

Let, for example, if $C=1$ is chosen, then we obtain the equation $A=(B+1) /(B-$ 1). This equation is also fulfilled by real numbers that are not equal to 1 . From the form of this equation it can be seen that there are infinitely many solutions to the given equation. By choosing for example $B=2$, then we get $A=3$. Thus, one solution to the equation is $A=3, B=2$, and $C=1$. Of course, this problem can be answered in different ways and with different answers: as long as the process is correct, the correct answer will be found.

\section{Collection of mathematics problems and examples of responses for senior high school teachers}

Table 3 contains a collection of mathematics problems from senior high school mathematics teachers. As in Table 1 and Table 2, the editorial of each problem in Table 3 has been corrected so that it is easier to read and understand. The collection of problems is again classified into two types: conceptual understanding and problem-solving problems. Ten mathematics problems were collected from our data collection: two problems are included in the conceptual understanding type, and eight problems are included in the problem-solving type. 
Table 3. Collection of mathematics problems from Senior High School Teachers

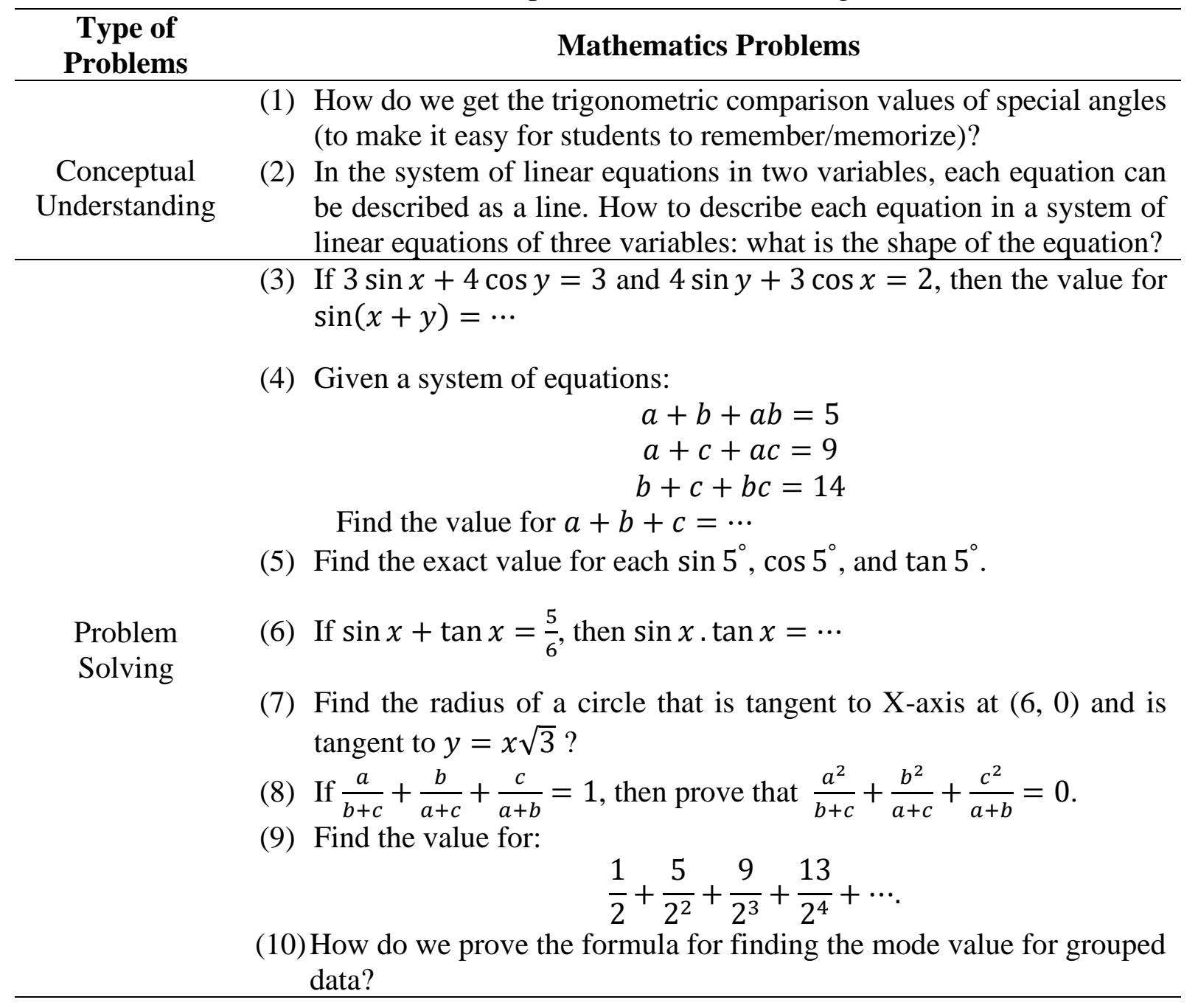

The following is an example of responses to problems asked by high school mathematics teachers. Example 5 presents the solution to Problem 9 in Table 3. This problem is categorized as a problem solving problem because the solution procedure requires a special trick that is often unthinkable for those who have never previously solved a similar problem.

Example 5. Find the value for:

\section{Solution.}

$$
\frac{1}{2}+\frac{5}{2^{2}}+\frac{9}{2^{3}}+\frac{13}{2^{4}}+\cdots .[\text { Problem } 9 \text { from Table 3.] }
$$

Let $\frac{1}{2}+\frac{5}{2^{2}}+\frac{9}{2^{3}}+\frac{13}{2^{4}}+\cdots=p$.

By multiplying both sides of the equation with $1 / 2$, then we obtain $\frac{1}{2^{2}}+\frac{5}{2^{3}}+\frac{9}{2^{4}}+\frac{13}{2^{5}}+\cdots=\frac{1}{2} p$.

By subtracting the second equation from the first equation, then we obtain

$\frac{1}{2}+\frac{4}{2^{2}}+\frac{4}{2^{3}}+\frac{4}{2^{4}}+\cdots=\frac{1}{2} p$.

$\Leftrightarrow \frac{1}{2}+4\left(\frac{\frac{1}{4}}{1-\frac{1}{2}}\right)=\frac{1}{2} p$. 


$$
\begin{aligned}
& \Leftrightarrow \frac{1}{2}+2=\frac{1}{2} p . \\
& \Leftrightarrow p=5 .
\end{aligned}
$$

\section{Therefore, we conclude that}

$\frac{1}{2}+\frac{5}{2^{2}}+\frac{9}{2^{3}}+\frac{13}{2^{4}}+\cdots=5$.

From the problems posed, especially in Table 3, it appears that the type of problemsolving problems that usually appear in mathematics competitions are often a challenge for high school mathematics teachers to be able to solve. When facing a new problem, which is nonroutine in nature, in finding a solution, teachers often need deep thinking, discussion, and even asking people who are competent in their field. Asking and discussing with experts in mathematics or mathematics education is one way that can be taken, which is proved helpful in dealing with daily mathematics problems at school levels. In today's digital era, asking and discussing does not have to be in a formal situation, in an informal and relaxed situation, it can also be done by using social media or other communication tools that are relevant and possible.

\section{Discussion}

Based on the description of the results in the previous section, we note two main points to be discussed. First, the problems proposed by mathematics teachers of the elementary, junior high school, senior high school, or equivalent levels, in general, can be classified into two types of problems: conceptual understanding and problem-solving. The conceptual understanding problems proposed by teachers, even if they look simple, are problems that require an understanding of mathematical concepts that are relational in nature, which relate one mathematical concept to other mathematical concepts, and require complex mathematical thinking skills that are not just asking the procedure for solving a problem (Budhi \& Kartasasmita, 2015; Posamentier \& Stepelman, 1990; Skemp, 1976). The problem-solving problems proposed by the teachers can often be categorized as non-routine problem-solving problems, often coming from mathematics competition, which requires the teachers to do proving processes, and require critical as well as creative thinking (Jupri et al., 2020; Koichu \& Leron, 2015; Levav-Waynberg \& Leikin, 2012; Weber, 2005). In addition, several problems proposed by the teachers having the type of problem-solving are open-ended problems, namely mathematics problems that require creativity, divergent thinking, both in terms of the problemsolving processes and of finding a variety of answers that meet the problems (Ho \& Hedberg, 2005; Koichu \& Leron, 2015; Kwon et al., 2006). Both conceptual understanding and problemsolving types of problems have challenged us, as a research team, to seriously use our experience and expertise in solving the problems posed to help teachers who need assistance in carrying out their duties at schools.

Second, the informal teacher development that we carried out for teachers, to a certain extent, can be regarded to be fruitful in helping teachers deal with practical mathematics problems in daily learning and teaching processes that require direct and immediate answers. The process of direct communication using social media such as Facebook, Instagram, 
and WhatsApp seems to reduce social barriers and the limitations of conventional face-to-face communication (Bagarukayo, 2018; Casey \& Wells, 2015). The teacher development process by using social media is almost without being limited by space and time, without the need to wait for the opportunity to meet directly between teachers and university lecturers in rigid, formal, and ceremonial situations. Through the use of features on Facebook or Instagram, the teachers in the communication processes seemed not too shy, reluctant, and embarrassed in asking questions to the research team as lecturers in universities. It is probably one of the advantages of using social media compared to other relatively conventional media. In our view, the interaction process using WhatsApp, particularly with the features of Chats and Video Call, is even more interactive, real-time, synchronous, and easier to do informally. We consider that the teacher development process that has been carried out will continue to be carried out without being limited by time and situation barriers. This kind of teacher development process seems to have advantages that can complement conventional mathematics teacher professional development shortcomings through face-to-face meetings informal situations.

\section{Conclusion}

Based on the description in the previous section, we conclude the following several points. First, the professional competence development that has been carried out informally in this study through social media, such as Facebook, Instagram, and WhatsApp, can be regarded as fruitful in helping teachers solve the problems they face in daily learning and teaching processes directly without being limited by space and time, without waiting for the opportunity to meet in person and rigid and formal situations. Second, the mathematics problems proposed by the teachers can be classified into conceptual understanding and problem-solving categories. Conceptual understanding problems are often related to pedagogical content knowledge on how to deliver to students in the learning and teaching processes, while problem-solving problems are often coming from mathematics competitions that need higher-order thinking skills. Third, some of the problems proposed by teachers may seem simple and trivial to some people, especially for university lecturers. However, it will be a valuable help for teachers who do not know if university lecturers who are experts in mathematics or mathematics education can help or provide guidance in solving them. Through this informal interaction, harmonious cooperation will be established between the elements of teachers and university lecturers in higher education.

As has been carried out, the informal mathematics teacher development process can be used as a model for other university lecturers in guiding teachers in their respective surrounding areas. In the future, these informal activities can be combined with formal activities in the form of face-to-face training and teacher development. In our view, if more complete data collection instruments, such as questionnaires and interviews, are used, then more comprehensive information can be collected, which can be used for better treatments in the processes of teacher development. Through this combination, formal and informal approaches, it is hoped that a closer relationship will be established between mathematics teachers and mathematicians and 
mathematics educators in higher education. If this is carried out continuously, the hope of improving the quality of mathematics education in Indonesia seems to be easier to achieve.

\section{Acknowledgments}

We thank mathematics teachers from various parts of Indonesia who participated actively in this study.

\section{Conflict of Interest}

The authors declare that no conflict of interest regarding the publication of this manuscript. In addition, the ethical issues, including plagiarism, misconduct, data fabrication and/or falsification, double publication and/or submission, and redundancies have been completely by the authors.

\section{References}

Anggranei, F. N. (2020). Realitas kompetensi guru pasca sertifikasi [The reality of postcertification teacher competence]. Scientific Journal of Reflection: Economic, Accounting, Management and Business, 3(4), 331-340. https://doi.org/10.37481/sjr.v3i4.229

Apud, A. (2020). Pengembangan profesi guru madrasah swasta di kota Serang [Professional development of private madrasah teachers in Serang city]. Nidhomul Haq: Jurnal Manajemen Pendidikan Islam, 5(1), 62-79. https://doi.org/10.31538/ndh.v5i1.519

Bagarukayo, E. (2018). Social media use to transfer knowledge into practice and aid interaction in higher education. International Journal of Education and Development Using ICT, 14(2), 211-232. https://www.learntechlib.org/p/184689/

Bissessar, C. S. (2014). Facebook as an informal teacher professional development tool. Australian Journal of Teacher Education, 39(2), 121-135. https://doi.org/10.14221/ajte.2014v39n2.9

Budhi, W. S., \& Kartasasmita, B. G. (2015). Berpikir matematis: Matematika untuk semua [Mathematical thinking: Math for all]. Erlangga.

Casey, G., \& Wells, M. (2015). Remixing to design learning: Social media and peer-to-peer interaction. Journal of Learning Design, 8(1), 38-54. https://doi.org/10.5204/jld.v8i1.225

Firman, H. (2007). Critical success factors untuk pengembangan lesson study berbasis MGMP: Pelajaran yang dipetik dari Kabupaten Sumedang [Critical success factors for developing MGMP-based lesson studies: Lessons learned from Sumedang district]. Seminar Nasional Exchange of Experiences on Best Practices of Lesson Study, Bandung.

Hendayana, S. (2007). Development of INSET model for improving teacher professionalism in Indonesia. NUE Journal of International Educational Cooperation, 2, 97-106. http://www.naruto-u.ac.jp/_files/00107792/journal_02_12_0.pdf

Ho, K. F., \& Hedberg, J. G. (2005). Teachers' pedagogies and their impact on students' mathematical problem solving. The Journal of Mathematical Behavior, 24(3-4), 238252. https://doi.org/10.1016/j.jmathb.2005.09.006

Jupri, A., Gozali, S. M., \& Usdiyana, D. (2020). An analysis of a geometry learning process: The case of proving area formulas. Prima: Jurnal Pendidikan Matematika, 4(2), 154163. https://doi.org/10.31000/prima.v4i2.2619 
Jupri, A., \& Rosjanuardi, R. (2020). An investigation of master student understanding on mathematical literacy problems. Jurnal Gantang, 5(1), 1-7. https://doi.org/10.31629/jg.v5i1.1828

Jupri, A., Sispiyati, R., \& Chin, K. E. (2021). An investigation of students' algebraic proficiency from a structure sense perspective. Journal on Mathematics Education, 12(1), 147-158. https://doi.org/10.22342/jme.12.1.13125.147-158

Koichu, B., \& Leron, B. (2015). Proving as problem solving: The role of cognitive decoupling. The Journal of Mathematical Behavior, 40, 233-244. https://doi.org/10.1016/j.jmathb.2015.10.005

Kwon, O. N., Park, J. H., \& Park, J. S. (2006). Cultivating divergent thinking in mathematics through an open-ended approach. Asia Pacific Education Review, 7(1), 51-61. https://doi.org/10.1007/BF03036784

Levav-Waynberg, A., \& Leikin, R. (2012). The role of multiple solution tasks in developing knowledge and creativity in geometry. The Journal of Mathematical Behavior, 31(1), 7390. https://doi.org/10.1016/j.jmathb.2011.11.001

Mustofa, M. (2007). Upaya pengembangan profesionalisme guru di Indonesia [Efforts to develop teacher professionalism in Indonesia]. Jurnal Ekonomi dan Pendidikan, 4(1), 7688. https://doi.org/10.21831/jep.v4i1.619

Patahuddin, S. M., \& Logan, T. (2019). Facebook as a mechanism for informal teacher professional learning in Indonesia. Teacher Development, 23(1), 101-120. https://doi.org/10.1080/13664530.2018.1524787

Polya, G. (1973). How to solve it: A new aspect of mathematical method (second edition). Princeton University Press. https://doi.org/10.2307/j.ctvc773pk

Posamentier, A. S., \& Stepelman, J. (1990). Teaching secondary school mathematics: Techniques and enrichment. Merrill. https://doi.org/10.1142/11583

Presiden Republik Indonesia. (2005). Undang-undang Republik Indonesia nomor 14 tahun 2005 tentang guru dan dosen [Law of the Republic of Indonesia number 14 of 2005 concerning teachers and lecturers]. Jakarta: Presiden Republik Indonesia.

Prihantoro, R. (2011). Pengembangan profesionalisme guru melalui model lesson study [Teacher professional development through the lesson study model]. Jurnal Pendidikan dan Kebudayaan, 17(1), 100-108. https://doi.org/10.24832/jpnk.v17i1.10

Rerendo, E. F., Pangesti, G. D., Mukarromah, N. A. A., Putri, V., Zulkardi, Z., \& Sari, N. (2021). Peningkatan keprofesionalan guru matematika selama pandemi melalui pelatihan dan pembinaan guru [Professional improvement of mathematics teachers during the pandemic through teacher training and guidance]. Jurnal Profesi Keguruan, 7(2), 156166.

Rohayati, A. (2008). Evaluasi dampak kegiatan lesson study pada kemampuan guru dalam mengelola pembelajaran matematika SMP di kabupaten Sumedang [Evaluation of the impact of lesson study activities on teachers' ability in managing Junior High School mathematics learning in Sumedang district]. International Conference on Lesson Study, Bandung.

Samo, D. D. (2017). Kemampuan pemecahan masalah matematika mahasiswa tahun pertama dalam memecahkan masalah geometri konteks budaya [Mathematics problem solving ability of first year students in solving cultural context geometric problems]. Jurnal Riset Pendidikan Matematika, 4(2), 141-152. https://doi.org/10.21831/jrpm.v4i2.13470

Skemp, R. R. (1976). Relational understanding and instrumental understanding. Mathematics Teaching, $77(1)$, 20-26. https://www.atm.org.uk/write/MediaUploads/Resources/Richard_Skemp.pdf

Suwartini, E. A. (2017). Supervisi akademik kepala sekolah, profesionalisme guru dan mutu pendidikan [Principal's academic supervision, teacher professionalism and quality of 
education]. Jurnal Administrasi Pendidikan, 24(2), 62-70. https://ejournal.upi.edu/index.php/JAPSPs/article/view/8294

Weber, K. (2005). Problem-solving, proving, and learning: The relationship between problemsolving processes and learning opportunities in the activity of proof construction. The Journal of Mathematical Behavior, 24(3-4), 351-360. https://doi.org/10.1016/j.jmathb.2005.09.005 